\title{
RESEARCH
}

Open Access

\section{Potential role of kaolin or potassium sulfate as anti-transpirant on improving physiological, biochemical aspects and yield of wheat plants under different watering regimes}

Maha Mohamed Shater Abdallah" ${ }^{1 *}$, Hala Mohamed Safwat El-Bassiouny ${ }^{1}$ and Mohamed Aly AbouSeeda ${ }^{2}$

\begin{abstract}
Background and objective: Certain substances with some physical and chemical activities can be used to decrease the transpiration rate and alleviate plant water stress through rising leaf resistance to the diffusion of water vapor. Wheat plant is considered as one of the most important and economic winter plants. So, the objective of this work is to evaluate the response of wheat plants (Triticum aestivum L.) cultivar Gimeza 7 to various concentrations of foliar application of anti-transpirant substances as kaolin (3 and 6\%), potassium sulfate (100 and $200 \mathrm{mg} / \mathrm{l})$.
\end{abstract}

Materials and methods: Two pot experiments were conducted during 2016/2017 and 2017/2018 successive growing winter seasons under greenhouse conditions at the Experimental Station, in the National Research Centre, Egypt. The plants were exposed to various levels of water holding capacity (WHC) 80, 60, and 40\%.

Results: Water stress led to a decrease in growth parameters, yield components, photosynthetic pigments, and carbohydrate contents as compared to $80 \%$ of WHC. Meanwhile, water stress caused significant increases in some compatible solute (total soluble sugar, free amino acids, and proline) and some antioxidant enzymes activities. Foliar treatments of wheat plants with kaolin or $\mathrm{K}_{2} \mathrm{SO}_{4}$ led to an increase in growth parameters, yield components, photosynthetic pigments, and carbohydrate constituents. More accumulation of the organic solutes of leaves (total soluble sugar and free amino acids), antioxidant enzyme activities, and some minerals ( $N, P, K$, and $C a$ ) was observed. Data also illustrated that the nutritional values of the grain yield of wheat were also improved when sprayed with kaolin and $\mathrm{K}_{2} \mathrm{SO}_{4}$.

Conclusion: The used substances are safe for the environment, and for the plant, potassium is an essential nutrient and its ability controls several biochemical and physiological responses in plants. Kaolin also can ameliorate plant physiology and consequently lead to higher yield production.

Keywords: Antioxidant enzymes, Kaolin, $\mathrm{K}_{2} \mathrm{SO}_{4}$, Wheat, Water stress

\footnotetext{
* Correspondence: maha_eg1908@yahoo.fr

'Botany Department, Agriculture and Biology Division, National Research

Centre, 33 El Bohouth St. Dokki, P.O. Box 12622, Giza, Egypt

Full list of author information is available at the end of the article
} 


\section{Introduction}

Water deficit is one of the main abiotic stresses, restricting the growth and productivity of plants and causes alternations in plant physiology and biochemistry (Bakry et al. 2016). It affects plant growth and development; decreases water potential, cell division, net photosynthesis, and protein synthesis; changes hormonal balance of the main plant tissue (Fathi and Tari 2016); and also leads to a loss in yield by reducing total biomass, relative water content, and chlorophyll content (Bakry et al. 2016). Drought stress resulted in the creation of reactive oxygen species (ROS) which lead to leave damage and so decreasing the crop growth and yield (Cakmak 2005).

Certain chemicals for several biological activities can be used to decrease the transpiration rate and alleviate plant water stress through rising leaf resistance to diffusion of water vapor. According to the mechanism of action, antitranspirant is divided into different groups, which are filmforming types (that cover leaf surface with thin coat which is unrealizable to water vapor), reflecting materials (which reflect backward a part of the radiation downfall on the upper surface of the leaves), and stomatal closing kinds (that influence the metabolic operations in leaf tissues) (Conde et al. 2016). Film-forming and reflecting antitranspirant were found to be non-toxic and have a longer period of effectiveness than metabolic types. Kaolin is a non-toxic aluminosilicate $\left(\mathrm{Al}_{4} \mathrm{Si}_{4} \mathrm{O}_{10}(\mathrm{OH})_{8}\right)$ clay mineral. Kaolin spray reduces leaf temperature through rising leaf reflectance which decreases transpiration rate more than the photosynthesis of plants grown at high solar radiation levels (Nakano and Uehara 1996). Studies by Cantore et al. (2009) reported that on tomato and potato, the foliar application of kaolin suspension reduces plant stress that is essential for the best plant growth, yield, and quality.

Plants adopted various mechanisms to survive with different stresses. The usage of minerals plays an important role in plant resistance versus abiotic stresses. Potassium is a necessary nutrient and it controls several biochemical and physiological responses of plants (Wang et al. 2013). Among the nutrients, $\mathrm{K}$ plays an essential role in growth development and participates significantly towards the plants' survival under drought stress. Saifullah et al. (2002) reported also that potassium plays an important role in different enzyme activities, photosynthesis, protein synthesis, osmoregulation, energy transfer, stomata movement, cation-anion balance, and stress tolerance, and thus, it is necessary for plants' growth. It is predestined that $\mathrm{K}$ has taken the vital place for the wheat physiological necessities. Whereas, wheat plant is the most important cereal crop due to its stabilized diet for the world population and participative with more calories and protein to the world diet more than any other cereal crop.

In the present study, we aim to focus on the effect of kaolin as physical anti-transpirant and $\mathrm{K}_{2} \mathrm{SO}_{4}$ as chemical anti-transpirant at different water regimes on growth and yield components of wheat plants and to improve the efficiency of wheat plants to resist water stress.

\section{Materials and methods \\ Experimental conditions, plant materials, growth, and treatment conditions}

Greenhouse experiments were conducted in the $\mathrm{Na}$ tional Research Centre during two successive winter seasons 2016/2017 and 2017/2018. Wheat grains (Triticum aestivum) cv. Gimeza 7 was obtained from Agriculture Research Centre Research Institute Giza, Egypt. Foliar application of wheat plants with antitranspirant (kaolin and $\mathrm{K}_{2} \mathrm{SO}_{4}$ ) was used to improve wheat drought tolerance under different levels of regimes. Grains were grown in pots (diameter $50 \mathrm{~cm}$ ), containing equal amounts of loam soil. The soil texture of the experimental site was loam and some physical and chemical properties of a representative soil sample are illustrated in Table 1 present in the Research Approach and Methodology according to the method described by Chapman and Pratt (1978).

Wheat grains were sown by the end of November. Fertilization was done with the recommended dose, i.e., (5 g phosphorous/pot as triple phosphate, $6 \mathrm{~g}$ nitrogen/ pot as urea, and $5 \mathrm{~g}$ potassium/pot as potassium sulfate) during the preparation of pots after sowing. The second dose of fertilization was added after 45 days from sowing as super phosphate $(5 \mathrm{~g} / \mathrm{pot})$, potassium sulfate $(25 \mathrm{~g} /$ pot), and urea $(6 \mathrm{~g} / \mathrm{pot})$ were used. The irrigation treatments were given to plants with different levels, $80 \%$, $60 \%$, and $40 \%$, of water holding capacity (WHC). To adjust the water holding capacity at $80 \%, 60 \%$ and $40 \%$ and the amount of water required to reach this level, the pots were weighed every week and the difference was added.

Kaolin concentrations $(0.0,1$, and $2 \%)$ and $\mathrm{K}_{2} \mathrm{SO}_{4}$ concentrations $(0.0,100$, and $200 \mathrm{mg} / \mathrm{l})$ were sprayed after 40 and 47 days of cultivation. Each treatment consisted of five replicates distributed in a completely randomized design system.

The treatments were as follows:

\begin{tabular}{llll}
\hline No. & Treatments & & \\
\hline 1 & Control at 80\% of WHC & 9 & $\mathrm{~K}_{2} \mathrm{SO}_{4}(100 \mathrm{mg} / \mathrm{l})+60 \% \mathrm{WHC}$ \\
2 & Kaolin 3\%+80\% WHC & 10 & $\mathrm{~K}_{2} \mathrm{SO}_{4}(200 \mathrm{mg} / \mathrm{l})+60 \% \mathrm{WHC}$ \\
3 & Kaolin 6\% + 80\% WHC & 11 & Control at 40\% of WHC \\
4 & $\mathrm{~K}_{2} \mathrm{SO}_{4}(100 \mathrm{mg} / \mathrm{l})+80 \% \mathrm{WHC}$ & 12 & $\mathrm{Kaolin} 3 \%+40 \% \mathrm{WHC}$ \\
5 & $\mathrm{~K}_{2} \mathrm{SO}_{4}(200 \mathrm{mg} / \mathrm{l})+80 \% \mathrm{WHC}$ & 13 & $\mathrm{Kaolin} 6 \%+40 \% \mathrm{WHC}$ \\
6 & Control at 60\% of WHC & 14 & $\mathrm{~K}_{2} \mathrm{SO}_{4}(100 \mathrm{mg} / \mathrm{l})+40 \% \mathrm{WHC}$ \\
7 & Kaolin 3\% +60\% WHC & 15 & $\mathrm{~K}_{2} \mathrm{SO}_{4}(200 \mathrm{mg} / \mathrm{l})+40 \% \mathrm{WHC}$ \\
8 & Kaolin 6\%+60\% WHC & & \\
\hline
\end{tabular}


Table 1 Physical and chemical soil properties of the experimental soil

\begin{tabular}{|c|c|c|c|c|c|c|c|c|c|c|}
\hline \multicolumn{3}{|c|}{ Macronutrient $\left(\mathrm{mg} \mathrm{Kg}^{-1}\right)$} & \multicolumn{4}{|c|}{ Cation (meq $\mathrm{I}^{-1}$ ) } & \multicolumn{4}{|c|}{ Anion (meq $\mathrm{I}^{-1}$ ) } \\
\hline $\mathrm{N}$ & P & K & $\mathrm{Na}^{+}$ & $\mathrm{K}^{+}$ & $\mathrm{Ca}^{+}$ & $\mathrm{Mg}^{+}$ & $\mathrm{CO}_{3}^{-}$ & $\mathrm{HCO}_{3}^{-}$ & $\mathrm{Cl}^{-}$ & $\mathrm{SO}_{4}^{-}$ \\
\hline 168.8 & 11.65 & 423.15 & 9.13 & 0.468 & 1.45 & 0.25 & 0.00 & 2.145 & 2.842 & 6.3 \\
\hline \multicolumn{4}{|c|}{ Particle size distribution (\%) } & \multicolumn{7}{|c|}{ Texture class loam } \\
\hline F. sand $\%$ & C. sand $\%$ & Silt $\%$ & Clay $\%$ & $\mathrm{pH}(1: 2.5)$ & EC (1:5) & O.C (\%) & O.M (\%) & \multicolumn{3}{|c|}{ WHC (mg $100 \mathrm{~g} \mathrm{soil}^{-1}$ ) } \\
\hline 25.89 & 9.28 & 47.38 & 13.19 & 6.83 & 1.12 & 0.75 & 1.30 & \multicolumn{3}{|l|}{21.0} \\
\hline
\end{tabular}

After 15 days from sowing, thinning was carried out, so 10 uniform plants were left in each pot. Five plants from each pot were used throughout the experimental period for biochemical analysis and the remaining five seedlings were left to grow for studying the effect of different treatments on the yield. Watering was carried out according to the water holding capacity. Samples were taken after 75 days from sowing to take the growth parameters (plant height, number of leaves/tiller, tiller fresh, and dry weight) and determine different biochemical aspects in plant leaves' photosynthetic pigments (chlorophyll a, chlorophyll b, and carotenoids), TSS, proline, free amino acids, lipid peroxi dation, antioxidant enzymes, nitrogen percentage, and the element compositions (potassium, sodium, calcium, and phosphorus). At harvest, the following characters were recorded on random samples of 10 plants to estimate the following characters: plant height (centimeters), spike length (centimeters), spike weight (grams), spikelet no./ spike, grain wt. (grams)/spike, and 1000 grains weight (grams), as well as the nutritive value of the grain yield, total carbohydrates percentage, protein percentage, nitrogen, phosphorus, and potassium and calcium contents.

\section{Biochemical analysis}

Photosynthetic pigments: total chlorophyll $\mathrm{a}$ and $\mathrm{b}$ and carotenoids contents in fresh leaves were determined using the method described by Lichtenthaler and Buschmann (2001). Total soluble sugars (TSS), were extracted and analyzed according to Homme et al., (1992) and Yemm, Willis, (1954). Determination of total carbohydrates carried out according to Herbert et al., (1971). Proline was assayed according to the method described by Bates et al. (1973). Free amino acid was determined with the ninhydrin reagent method of Yemm and Cocking (1955). Lipid peroxidation was determined by measuring the amount of produced malondialdehyde (MDA) by the thiobarbituric acid (TBA) reaction as described by Predieri et al. (1995). The antioxidant enzyme (peroxidase (POX, EC 1.11.1.7) activity was assayed spectrophotometrically by the method described by Kumar and Khan (1982). Superoxide dismutase (SOD, EC 1.12.1.1) and catalase (CAT, EC 1.11.1.6) activity assayed spectropho tometrically by following the decrease in absorbance at 560 and $240 \mathrm{~nm}$, respectively, according to Chen and Wang (2006). Total $\mathrm{N}$ was determined by using the micro-Kjeldahl method as described in AOAC (1970). Macro- element contents of the leaves and yielded grains were determined according to Chapman and Pratt (1978). Phosphorus was determined using a Spekolspectro colorimeter (VEB Carl Zeiss; Jena, Germany), while the estimation of $\mathrm{K}+$ contents was done using a flame photometer.

\section{Statistical analysis}

The experimental design is a factorial experiment with two factors in a completely randomized design. The two factors were watering regimes and anti-transpirant substances using kaolin and potassium sulfate. The irrigation regimes were maintaining wheat plants at different levels of $80 \%, 60 \%$, and $40 \%$ of water holding capacity (WHC). The anti-transpirant substances utilized kaolin concentrations at $0.0,3$, and $6 \%$ and potassium sulfate at 0.0, 100, and $200 \mathrm{mg} / \mathrm{l}$. The data were statistically analyzed according to Snedecor and Cochran (1980); combined analysis of the two growing seasons was carried out. Means were compared by using the least significant difference (LSD) at $5 \%$ levels of probability.

\section{Results \\ Plant growth}

Table 2 showed the influence of the foliar application of different concentrations of kaolin and $\mathrm{K}_{2} \mathrm{SO}_{4}$ on growth criteria of wheat plants subjected to different levels of water holding capacity (WHC). Exposure of plants to 60\% and $40 \%$ of WHC in the soil induced significant decrease in the morphological parameters (plant height, number of leaves/plant, plant fresh, and dry weight) when compared to a plant grown under $80 \%$ WHC. Treatment of wheat plants with different concentrations of kaolin and $\mathrm{K}_{2} \mathrm{SO}_{4}$ significantly increased all growth criteria under different water levels as compared with the corresponding WHC. Maximum increases in plant fresh and dry weight were obtained by using high concentration $\mathrm{K}_{2} \mathrm{SO}_{4}(200 \mathrm{mg} / \mathrm{l})$ and kaolin $6 \%$ under different WHC levels. 
Table 2 Effect of different concentrations of kaolin or $\mathrm{K}_{2} \mathrm{SO}_{4}$ under different levels of water holding capacity on morphological criteria and area of stomata (upper and lower epidermis) of wheat plants after 75 days from sowing combined analysis of two seasons)

\begin{tabular}{|c|c|c|c|c|c|c|c|c|}
\hline \multirow{2}{*}{$\begin{array}{l}\text { WHC } \\
(\%)\end{array}$} & \multirow[t]{2}{*}{ Treatment } & \multirow{2}{*}{$\begin{array}{l}\text { Plant height } \\
(\mathrm{cm})\end{array}$} & \multirow{2}{*}{$\begin{array}{l}\text { Leaf no./ } \\
\text { tiller }\end{array}$} & \multirow{2}{*}{$\begin{array}{l}\text { Tiller Fr. } \\
\text { wt. }(g)\end{array}$} & \multirow{2}{*}{$\begin{array}{l}\text { Tiller Dr. } \\
\text { wt. (g) }\end{array}$} & \multirow{2}{*}{$\begin{array}{l}\text { Amount of } \\
\text { water (g) }\end{array}$} & \multicolumn{2}{|c|}{ Stomatal area $\mu m^{2}$} \\
\hline & & & & & & & Upper & Lower \\
\hline \multirow[t]{5}{*}{$80 \%$} & Control & 52.63 & 5.33 & 3.542 & 0.981 & 2.561 & 166 & 100 \\
\hline & Kaolin 3\% & 54.52 & 5.50 & 5.121 & 1.238 & 3.883 & 154 & 96 \\
\hline & Kaolin 6\% & 62.66 & 6.33 & 6.523 & 1.265 & 5.258 & 131 & 123 \\
\hline & $\mathrm{K}_{2} \mathrm{SO}_{4}(100 \mathrm{mg} / \mathrm{l})$ & 69.23 & 6.00 & 6.306 & 1.220 & 5. 086 & 200 & 105 \\
\hline & $\mathrm{K}_{2} \mathrm{SO}_{4}(200 \mathrm{mg} / \mathrm{l})$ & 65.70 & 6.00 & 6.490 & 1.300 & 5.190 & 183 & 90 \\
\hline \multirow[t]{5}{*}{$60 \%$} & Control & 57.63 & 5.03 & 3.422 & 0.953 & 2.469 & 118 & 64 \\
\hline & Kaolin 3\% & 59.54 & 6.00 & 5.401 & 1.088 & 4.313 & 110 & 73 \\
\hline & Kaolin 6\% & 58.30 & 5.33 & 5.660 & 1.185 & 4.475 & 92 & 54 \\
\hline & $\mathrm{K}_{2} \mathrm{SO}_{4}(100 \mathrm{mg} / \mathrm{l})$ & 64.77 & 5.67 & 5.583 & 1.131 & 4.452 & 108 & 85 \\
\hline & $\mathrm{K}_{2} \mathrm{SO}_{4}(200 \mathrm{mg} / \mathrm{l})$ & 62.00 & 5.67 & 5.784 & 1.268 & 4.516 & 69 & 42 \\
\hline \multirow[t]{5}{*}{$40 \%$} & Control & 55.67 & 4.69 & 3.117 & 0.792 & 2.325 & 29 & 26 \\
\hline & Kaolin 3\% & 64.53 & 5.33 & 4.405 & 0.834 & 3.571 & 38 & 31 \\
\hline & Kaolin 6\% & 64.23 & 5.67 & 4.483 & 0.882 & 3.601 & 36 & 28 \\
\hline & $\mathrm{K}_{2} \mathrm{SO}_{4}(100 \mathrm{mg} / \mathrm{l})$ & 59.90 & 5.80 & 4.461 & 0.848 & 3.613 & 64 & 44 \\
\hline & $\mathrm{K}_{2} \mathrm{SO}_{4}(200 \mathrm{mg} / \mathrm{l})$ & 61.67 & 5.83 & 4.620 & 0.893 & 3.727 & 35 & 28 \\
\hline \multicolumn{2}{|c|}{ LSD at $5 \%$} & 0.07 & 0.10 & 0.071 & 0.071 & 0.033 & 0.041 & 3.90 \\
\hline
\end{tabular}

\section{Stomata opening area}

In the present work, leaf stomatal area was significantly reduced with decreasing WHC percentage and with different treatments, as shown in (Table 2). The application of kaolin induced significant decrease in the stomata opening at upper and lower epidermis as compared with the corresponding control at $80 \%$ WHC except for kaolin at $6 \%$ induced significant increase in the lower epidermis. $\mathrm{K}_{2} \mathrm{SO}_{4}$ induced significant increase in the stomata opening in the upper and lower epidermis as compared to the control except for $\mathrm{K}_{2} \mathrm{SO}_{4} \quad(200 \mathrm{mg} / \mathrm{l})$ at the lower epidermis. At $60 \%$ WHC, kaolin (3\%) and $\mathrm{K}_{2} \mathrm{SO}_{4}(100 \mathrm{mg} /$ l) induced significant increase in the stomatal area of the lower epidermis, while the upper epidermis induced significant decrease as compared with the corresponding controls. On the other hand, kaolin (6\%) and K2SO4 (200 $\mathrm{mg} / \mathrm{l})$ at $60 \%$ WHC induced the significant decrease in the stomata opening in the upper and lower epidermis as compared with the corresponding controls. At $40 \% \mathrm{WHC}$, kaolin and $\mathrm{K}_{2} \mathrm{SO}_{4}$ induced significant increase in the stomatal opening area in both upper and lower epidermis as compared with the controls at 40\% WHC.

\section{Photosynthetic pigments}

The data given in Table 3 illustrated the influence of different concentrations of kaolin and $\mathrm{K}_{2} \mathrm{SO}_{4}$ on photosynthetic pigments (chlorophyll a, chlorophyll b, carotenoids, and total pigments) in wheat leaves under different levels of WHC. The decrease in WHC of soil to $60 \%$ and $40 \%$ induced significant reduction in photosy nthetic pigments as compared to $80 \%$ of water holding capacity (WHC). Wheat plants treated with different concentrations of kaolin and $\mathrm{K}_{2} \mathrm{SO}_{4}$ significantly increased photosynthetic pigments under different water levels as compared with the corresponding WHC. Maximum increases in total pigments were obtained by using 6\% kaolin at $80 \% \mathrm{WHC}, 3 \%$ kaolin at $60 \% \mathrm{WHC}$, and $\mathrm{K}_{2} \mathrm{SO}_{4}$ $200 \mathrm{mg} / \mathrm{l}$ at $40 \% \mathrm{WHC}$. The ratio of increase was $12 \%, 9 \%$, and $16 \%$, respectively, as compared with the corresponding WHC levels.

\section{Carbohydrates, proline, and free amino acid contents}

The results in Table 4 illustrated that decreasing WHC to $60 \%$ and $40 \%$ induced an accumulation of compatible solutes (total soluble sugar proline and free amino acid) in plants. Treatment of wheat plants with different concentrations of kaolin and $\mathrm{K}_{2} \mathrm{SO}_{4}$ induced an additive increases in TSS and free amino acid content as compared with the corresponding control at WHC level. Concerning proline, $\mathrm{K}_{2} \mathrm{SO}_{4}$ induced an increase, while kaolin led to a decrease of $60 \%$ and $40 \%$ of WHC. Exposure of plants to $60 \%$ and $40 \%$ of WHC in the field conditions induced significant decrease in total carbohydrate contents as compared to $80 \%$ of water holding capacity. Foliar spray of different concentrations of kaolin and $\mathrm{K}_{2} \mathrm{SO}_{4}$ to wheat plants under the various levels of WHC caused an 
Table 3 Effect of different concentrations of kaolin or $\mathrm{K}_{2} \mathrm{SO}_{4}$ under different levels of water holding capacity on photosynthetic pigments ( $\mathrm{g} / \mathrm{g}$ fresh weight) of wheat plants after 75 days from sowing (combined analysis of two seasons)

\begin{tabular}{|c|c|c|c|c|c|}
\hline$\overline{W H C}(\%)$ & Treatment & $\mathrm{Chl} \mathrm{a}$ & $\mathrm{Chl} \mathrm{b}$ & Carotenoids & Total pigments \\
\hline \multirow[t]{5}{*}{$80 \%$} & Control & 11.63 & 12.05 & 3.63 & 27.31 \\
\hline & Kaolin 3\% & 11.60 & 12.17 & 3.44 & 27.21 \\
\hline & Kaolin 6\% & 14.25 & 13.25 & 3.33 & 30.84 \\
\hline & $\mathrm{K}_{2} \mathrm{SO}_{4}(100 \mathrm{mg} / \mathrm{l})$ & 14.46 & 10.96 & 4.06 & 29.48 \\
\hline & $\mathrm{K}_{2} \mathrm{SO}_{4}(200 \mathrm{mg} / \mathrm{l})$ & 14.54 & 10.15 & 4.08 & 28.77 \\
\hline \multirow[t]{5}{*}{$60 \%$} & Control & 12.59 & 9.51 & 4.29 & 26.39 \\
\hline & Kaolin 3\% & 14.50 & 10.18 & 4.12 & 28.80 \\
\hline & Kaolin 6\% & 14.53 & 9.30 & 4.27 & 28.10 \\
\hline & $\mathrm{K}_{2} \mathrm{SO}_{4}(100 \mathrm{mg} / \mathrm{l})$ & 14.36 & 8.69 & 4.39 & 27.45 \\
\hline & $\mathrm{K}_{2} \mathrm{SO}_{4}(200 \mathrm{mg} / \mathrm{l})$ & 14.52 & 9.49 & 4.36 & 28.36 \\
\hline \multirow[t]{5}{*}{$40 \%$} & Control & 10.53 & 7.45 & 4.79 & 22.77 \\
\hline & Kaolin 3\% & 12.07 & 7.88 & 4.51 & 24.46 \\
\hline & Kaolin 6\% & 13.60 & 7.32 & 4.96 & 25.88 \\
\hline & $\mathrm{K}_{2} \mathrm{SO}_{4}(100 \mathrm{mg} / \mathrm{l})$ & 12.61 & 8.53 & 4.53 & 25.67 \\
\hline & $\mathrm{K}_{2} \mathrm{SO}_{4}(200 \mathrm{mg} / \mathrm{l})$ & 13.64 & 8.42 & 4.49 & 26.55 \\
\hline \multicolumn{2}{|l|}{ LSD at $5 \%$} & 0.21 & 0.26 & 0.19 & 0.35 \\
\hline
\end{tabular}

Table 4 Effect of different concentrations of kaolin or $\mathrm{K}_{2} \mathrm{SO}_{4}$ under different levels of water holding capacity on total soluble sugar (TSS), proline, and free amino acid (FAA) (mg/100 g dry weight) and carbohydrate contents ( $\mathrm{mg} / \mathrm{g}$ dry weight) of wheat plants after 75 days from sowing (combined analysis of two seasons)

\begin{tabular}{|c|c|c|c|c|c|}
\hline$\overline{\mathrm{WHC}}(\%)$ & Treatment & TSS & Carbohydrates & Proline & $\overline{F A A}$ \\
\hline \multirow[t]{5}{*}{$80 \%$} & Control & 1370 & 270.7 & 139.4 & 256.4 \\
\hline & Kaolin 3\% & 1514 & 288.3 & 237.2 & 28 \\
\hline & Kaolin 6\% & 2172 & 318.8 & 146.8 & 458.3 \\
\hline & $\mathrm{K}_{2} \mathrm{SO}_{4}(100 \mathrm{mg} / \mathrm{l})$ & 1606 & 339.4 & 157.6 & 3641 \\
\hline & $\mathrm{K}_{2} \mathrm{SO}_{4}(200 \mathrm{mg} / \mathrm{l})$ & 2035 & 363.8 & 196.3 & 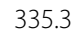 \\
\hline \multirow[t]{5}{*}{$60 \%$} & Control & 1638 & 340.8 & 179.2 & 387.5 \\
\hline & Kaolin 3\% & 2215 & 356.7 & 169.8 & 472.2 \\
\hline & Kaolin 6\% & 1999 & 392.9 & 142.5 & 529.0 \\
\hline & $\mathrm{K}_{2} \mathrm{SO}_{4}(100 \mathrm{mg} / \mathrm{l})$ & 1927 & 366.4 & 183.9 & 482.7 \\
\hline & $\mathrm{K}_{2} \mathrm{SO}_{4}(200 \mathrm{mg} / \mathrm{l})$ & 2114 & 363.0 & 201.4 & 480.2 \\
\hline \multirow[t]{5}{*}{$40 \%$} & Control & 1610 & 314.5 & 229.0 & 534.4 \\
\hline & Kaolin 3\% & 2012 & 323.3 & 202.3 & 588.7 \\
\hline & Kaolin 6\% & 1744 & 346.5 & 151.6 & 665.1 \\
\hline & $\mathrm{K}_{2} \mathrm{SO}_{4}(100 \mathrm{mg} / \mathrm{l})$ & 1726 & 339.5 & 229.8 & 54 \\
\hline & $\mathrm{K}_{2} \mathrm{SO}_{4}(200 \mathrm{mg} / \mathrm{l})$ & 1988 & 364.3 & 331.1 & 834.0 \\
\hline LSD at $5 \%$ & & 20.1 & 13.01 & 6.47 & 6.86 \\
\hline
\end{tabular}

increase in the carbohydrate contents as compared with the corresponding WHC levels (Table 4).

\section{Lipid peroxidation}

Results revealed that wheat plant exposed to $60 \%$ and $40 \%$ of WHC showed a gradual and significant increase in malondialdehyde (MDA) compared to a control plant at $80 \%$ of WHC (Table 5). The high level of MDA concentration in plant leaves indicated that it is affected by water stress exhibited by lipid peroxidation, which resulted in membrane damage. However, the plants that subjected to $\mathrm{K}_{2} \mathrm{SO}_{4}$ or kaolin exhibited lower values for MDA content as compared with the corresponding controls at WHC levels.

\section{Antioxidant enzyme}

The change in the activity of peroxidase (POX), in the leaves of wheat plants exposed to water stress $(60 \%$ and $40 \%$ WHC) were significantly increased, as compared with control plants particularly at $80 \%$ of WHC (Table 5). The super oxide dismutase (SOD) and catalase (CAT) were decreased by decreasing the WHC from $60 \%$ to $40 \%$. Application of kaolin or $\mathrm{K}_{2} \mathrm{SO}_{4}$ under water stress conditions (60\% and 40\%), POX, SOD, and CAT activities were markedly enhanced as compared to control plants. The maximum increase in SOD activity was recorded in plants sprayed with $\mathrm{K}_{2} \mathrm{SO}_{4}(100 \mathrm{mg} / \mathrm{l})$, whereas POX activity was observed in plants treated

Table 5 Effect of different concentrations of kaolin or $\mathrm{K}_{2} \mathrm{SO}_{4}$ under different levels of water holding capacity on lipid peroxidation ( $\mu \mathrm{g}$ malondialdehyde/g fresh weight) and antioxidant enzyme activity ( $g$ fresh weight/h) of wheat plants after 75 days from sowing (combined analysis of two seasons)

\begin{tabular}{llllll}
\hline WHC (\%) & Treatment & Lipid peroxidation & POX & SOD & CAT \\
\hline $80 \%$ & Control & 20.87 & 26.04 & 96.24 & 96.84 \\
& Kaolin 3\% & 17.12 & 36.84 & 84.48 & 23.82 \\
& Kaolin 6\% & 16.32 & 33.49 & 82.36 & 48.96 \\
& $\mathrm{~K}_{2} \mathrm{SO}_{4}(100 \mathrm{mg} / \mathrm{l})$ & 15.74 & 46.44 & 56.27 & 81.18 \\
& $\mathrm{~K}_{2} \mathrm{SO}_{4}(200 \mathrm{mg} / \mathrm{l})$ & 17.18 & 64.14 & 45.66 & 66.60 \\
$60 \%$ & Control & 21.82 & 46.14 & 24.81 & 25.40 \\
& Kaolin 3\% & 19.72 & 68.67 & 55.58 & 43.86 \\
& Kaolin 6\% & 18.91 & 48.98 & 44.58 & 82.04 \\
& $\mathrm{~K}_{2} \mathrm{SO}_{4}(100 \mathrm{mg} / \mathrm{l})$ & 16.84 & 46.59 & 78.44 & 86.82 \\
& $\mathrm{~K}_{2} \mathrm{SO}_{4}(200 \mathrm{mg} / \mathrm{l})$ & 17.64 & 58.34 & 63.33 & 122.46 \\
& $\mathrm{Control}_{40 \%}$ & 25.74 & 41.67 & 21.00 & 20.14 \\
& $\mathrm{Kaolin}_{3} \%$ & 21.56 & 64.52 & 44.34 & 87.98 \\
& $\mathrm{Kaolin}_{6} \%$ & 20.80 & 45.51 & 86.18 & 114.58 \\
& $\mathrm{~K}_{2} \mathrm{SO}_{4}(100 \mathrm{mg} / \mathrm{l})$ & 22.34 & 52.62 & 140.79 & 69.78 \\
& $\mathrm{~K}_{2} \mathrm{SO}_{4}(200 \mathrm{mg} / \mathrm{l})$ & 21.18 & 44.90 & 118.92 & 71.58 \\
& & 0.20 & 4.01 & 4.67 & 4.67 \\
\hline
\end{tabular}


with 3\% kaolin. The highest CAT activity was observed in plants treated with $\mathrm{K}_{2} \mathrm{SO}_{4}(200 \mathrm{mg} / \mathrm{l})$ particularly at $60 \% \mathrm{WHC}$ and kaolin $6 \%$ at $40 \% \mathrm{WHC}$ as well.

\section{Minerals nutrition contents}

The decrease of WHC to $60 \%$ and $40 \%$ in the soil induced significant increases in $\mathrm{N}$ percentage, $\mathrm{K}$ percentage ,and Ca percentage as compared to $80 \%$ of WHC. However, $\mathrm{P}$ and $\mathrm{Na}$ showed a significant increase particularly at $60 \%$ of WHC and then decrease at $40 \%$ of WHC as compared to $80 \%$ of WHC (Table 6). Foliar spray at different concentrations of kaolin and $\mathrm{K}_{2} \mathrm{SO}_{4}$ to wheat plants under various levels of $\mathrm{WHC}$ caused a significant increase in the $\mathrm{N}, \mathrm{K}$, and $\mathrm{Ca}$ percentage as compared with the corresponding WHC levels (Table 6), while $\mathrm{P}$ and $\mathrm{Na}$ contents induced variable changes at different WHC levels.

\section{Yield components}

The results in Table 7 showed the influence of different concentrations of kaolin and $\mathrm{K}_{2} \mathrm{SO}_{4}$ on yield parameters of wheat plants under various water holding capacity levels. Exposure of plants to $60 \%$ and $40 \%$ of WHC leads to a significant decrease in all yield parameters studied as compared to $80 \%$ of WHC except the plant height. Treatment of wheat plants with different concentrations of kaolin and $\mathrm{K}_{2} \mathrm{SO}_{4}$ increased all yield parameters under different water levels as compared with the corresponding controls of WHC. The maximum increases in grain weight/spike and

Table 6 Effect of different concentrations of kaolin or $\mathrm{K}_{2} \mathrm{SO}_{4}$ under different levels of water holding capacity on N, P, K, Na, and $\mathrm{Ca}$ percentage of wheat plants after 75 days from sowing (combined analysis of two seasons)

\begin{tabular}{lllllll}
\hline WHC (\%) & Treatment & $\mathrm{N} \%$ & $\mathrm{P} \%$ & $\mathrm{~K} \%$ & $\mathrm{Na} \%$ & $\mathrm{Ca} \%$ \\
\hline $80 \%$ & Control & 2.594 & 0.277 & 0.460 & 0.105 & 0.297 \\
& Kaolin 3\% & 2.991 & 0.284 & 0.656 & 0.232 & 0.566 \\
& Kaolin 6\% & 3.296 & 0.335 & 0.632 & 0.118 & 0.542 \\
& $\mathrm{~K}_{2} \mathrm{SO}_{4}(100 \mathrm{mg} / \mathrm{l})$ & 3.418 & 0.284 & 0.712 & 0.334 & 0.481 \\
& $\mathrm{~K}_{2} \mathrm{SO}_{4}(200 \mathrm{mg} / \mathrm{l})$ & 3.296 & 0.292 & 0.696 & 0.118 & 0.301 \\
$60 \%$ & Control & 3.010 & 0.285 & 0.604 & 0.188 & 0.376 \\
& Kaolin 3\% & 3.991 & 0.239 & 0.708 & 0.139 & 0.470 \\
& Kaolin 6\% & 3.662 & 0.299 & 0.652 & 0.121 & 0.397 \\
& $\mathrm{~K}_{2} \mathrm{SO}_{4}(100 \mathrm{mg} / \mathrm{l})$ & 3.510 & 0.250 & 0.637 & 0.146 & 0.470 \\
& $\mathrm{~K}_{2} \mathrm{SO}_{4}(200 \mathrm{mg} / \mathrm{l})$ & 3.552 & 0.276 & 0.648 & 0.117 & 0.393 \\
& $\mathrm{Control}_{40 \%}$ & 3.115 & 0.243 & 0.652 & 0.086 & 0.373 \\
& $\mathrm{Kaolin}_{6} \%$ & 3.205 & 0.216 & 1.268 & 0.141 & 0.446 \\
& $\mathrm{Kaolin}_{6} \%$ & 3.906 & 0.207 & 0.696 & 0.130 & 0.446 \\
& $\mathrm{~K}_{2} \mathrm{SO}_{4}(100 \mathrm{mg} / \mathrm{l})$ & 3.784 & 0.267 & 0.658 & 0.117 & 0.395 \\
& $\mathrm{~K}_{2} \mathrm{SO}_{4}(200 \mathrm{mg} / \mathrm{l})$ & 3.662 & 0.205 & 0.660 & 0.112 & 0.434 \\
& & 0.005 & 0.022 & 0.006 & 0.037 & 0.007 \\
\hline \multirow{6}{*}{$\mathrm{LSD}$ at 5\% } & & & & & &
\end{tabular}

weight of 1000 grains were obtained by using $200 \mathrm{mg} / \mathrm{l}$ $\mathrm{K}_{2} \mathrm{SO}_{4}$ as compared to the corresponding controls at WHC levels. The percentages of increase were $60 \%$, $42 \%$, and $36 \%$ in grain weight/spike and $20 \%, 25 \%$, and $16 \%$ weight of 1000 grains at $80 \%, 60 \%$, and $40 \% \mathrm{WHC}$, respectively, as compared with the corresponding controls at WHC levels.

\section{Carbohydrate percentage and protein percentage of grain yield}

The reduction of WHC to $60 \%$ and $40 \%$ in the soil induced significant decreases in the percentage of carbohydrates percentage and protein percentage in the yielded grains as compared to $80 \%$ of water holding capacity. Foliar spray of different concentrations of kaolin and $\mathrm{K}_{2} \mathrm{SO}_{4}$ to wheat plants under the different levels of WHC caused an increase in the carbohydrate percentage and protein percentage as compared with the corresponding WHC levels (Table 8).

\section{Mineral nutrients in grain yield}

The decrease of WHC to $60 \%$ and $40 \%$ in the soil induced significant increases in $\mathrm{N}, \mathrm{K}^{+}$, and $\mathrm{Ca}^{2+} \%$ in $60 \%$ WHC and then decreases at $40 \%$ WHC as compared to $80 \%$ of water holding capacity. Foliar spray of different concentrations of kaolin and $\mathrm{K}_{2} \mathrm{SO}_{4}$ under different levels of WHC caused a significant increase in the percentage of $\mathrm{N}, \mathrm{K}^{+}$, and $\mathrm{Ca}$ as compared with the corresponding WHC levels (Table 8), while phosphorus induced a non-significant change.

\section{Discussion}

Plant growth

The exposure of plants to $60 \%$ and $40 \%$ WHC led to a marked decrease in all morphological parameter. The reduction in the growth parameters may be attributed to losses of tissue water which inhibited cell division and enlargement, or possibly to a decrease in the activity of meristematic tissues responsible for elongation (Siddique et al. 1999; El Sebai et al. 2016). Moreover, total FW and DW decreased due to the exposure to low levels of drought which might have resulted from a reduction in chlorophyll content and consequently, photosynthetic efficiency (Bakry et al. 2012).

The data in Table 2 illustrated that foliar application of different concentrations of kaolin and $\mathrm{K}_{2} \mathrm{SO}_{4}$ induced significant increases on growth criteria. Whereas, kaolin led to the reduction in the transpiration rate that led to keep higher water content in the plant tissues and hence might favor the plant metabolism, the physiological processes, photosynthetic rate, carbohydrate metabolism, and many other important functions that directly affect plant growth. In this respect, studies conducted on tomato and potato showed that kaolin application 
Table 7 Effect of different concentrations of kaolin or $\mathrm{K}_{2} \mathrm{SO}_{4}$ under different levels of water holding capacity on yield components of wheat plants (combined analysis of two seasons)

\begin{tabular}{|c|c|c|c|c|c|c|c|c|}
\hline$\overline{W H C}(\%)$ & Treatment & Plant height $(\mathrm{cm})$ & Spike length $(\mathrm{cm})$ & Spike wt. (g) & $\begin{array}{l}\text { Spikelet } \\
\text { no. /spike }\end{array}$ & Grain no./spike & Grain wt. (g)/spike & $\begin{array}{l}\text { Weight of } \\
1000 \text { grains (g) }\end{array}$ \\
\hline \multirow[t]{5}{*}{$80 \%$} & Control & 63.51 & 10.33 & 1.82 & 14.00 & 36.50 & 1.415 & 39.62 \\
\hline & Kaolin 3\% & 64.62 & 11.67 & 2.04 & 16.33 & 39.33 & 1.543 & 39.81 \\
\hline & Kaolin 6\% & 66.03 & 12.33 & 2.15 & 15.67 & 43.50 & 1.950 & 44.23 \\
\hline & $\mathrm{K}_{2} \mathrm{SO}_{4}(100 \mathrm{mg} / \mathrm{l})$ & 70.14 & 12.33 & 2.48 & 16.33 & 45.67 & 2.099 & 45.15 \\
\hline & $\mathrm{K}_{2} \mathrm{SO}_{4}(200 \mathrm{mg} / \mathrm{l})$ & 69.00 & 12.00 & 2.43 & 15.33 & 49.33 & 2.271 & 47.68 \\
\hline \multirow[t]{5}{*}{$60 \%$} & Control & 58.33 & 10.00 & 1.79 & 14.00 & 33.50 & 1.311 & 38.43 \\
\hline & Kaolin 3\% & 61.88 & 13.00 & 2.33 & 15.67 & 38.40 & 1.576 & 41.36 \\
\hline & Kaolin 6\% & 62.60 & 13.33 & 2.45 & 15.00 & 44.50 & 1.843 & 42.83 \\
\hline & $\mathrm{K}_{2} \mathrm{SO}_{4}(100 \mathrm{mg} / \mathrm{l})$ & 61.00 & 12.33 & 2.26 & 14.33 & 41.00 & 1.855 & 44.99 \\
\hline & $\mathrm{K}_{2} \mathrm{SO}_{4}(200 \mathrm{mg} / \mathrm{l})$ & 61.33 & 12.67 & 2.73 & 14.33 & 40.33 & 1.896 & 48.00 \\
\hline \multirow[t]{5}{*}{$40 \%$} & Control & 57.00 & 9.33 & 1.64 & 14.00 & 26.67 & 1.149 & 35.94 \\
\hline & Kaolin 3\% & 59.33 & 10.33 & 2.00 & 14.33 & 29.67 & 1.289 & 39.32 \\
\hline & Kaolin 6\% & 58.07 & 13.00 & 1.91 & 13.67 & 32.33 & 1.297 & 40.66 \\
\hline & $\mathrm{K}_{2} \mathrm{SO}_{4}(100 \mathrm{mg} / \mathrm{l})$ & 59.00 & 12.33 & 1.95 & 14.33 & 36.67 & 1.554 & 41.20 \\
\hline & $\mathrm{K}_{2} \mathrm{SO}_{4}(200 \mathrm{mg} / \mathrm{l})$ & 59.67 & 12.00 & 1.98 & 14.00 & 34.33 & 1.559 & 41.59 \\
\hline LSD at $5 \%$ & & 2.39 & 0.36 & 0.15 & 0.67 & 3.28 & 0.008 & 0.23 \\
\hline
\end{tabular}

gradually decreases plant stress, which is vital for plant growth and quality of yield Cantore et al. (2009). Moreover, Segura-Monroy et al. (2015) observed that kaolin enhanced the plant height, and plant dry weight, of Physalisperuviana L. seedlings. Khalil (2006) reported that all anti-transpirants (film-forming, stomata, and reflecting) significantly increased all growth parameters of sesame (Sesamum indicum) plants compared with the control treatment.

Potassium is required for the plant growth; it plays an essential function in enzyme activities, stomatal opening and closing mechanism, and photosynthesis (Golldack et al. 2003). Abdelaziz and Abdeldaym (2018) demonstrated that foliar potassium rates resulted in significant increases in

Table 8 Effect of different concentrations of kaolin or $\mathrm{K}_{2} \mathrm{SO}_{4}$ under different levels of water holding capacity on carbohydrate percentage, protein percentage, and elements ( $, P, K$, and Ca \%) of wheat grains (combined analysis of two seasons)

\begin{tabular}{|c|c|c|c|c|c|c|c|}
\hline$\overline{W H C}(\%)$ & Treatment & Carbohydrates \% & Protein \% & $\mathrm{N} \%$ & $\mathrm{P} \%$ & $\mathrm{~K} \%$ & Ca \% \\
\hline \multirow[t]{5}{*}{$80 \%$} & Control & 52.76 & 12.11 & 1.94 & 0.38 & 0.42 & 0.017 \\
\hline & Kaolin 3\% & 58.93 & 13.96 & 2.23 & 0.39 & 0.47 & 0.023 \\
\hline & Kaolin 6\% & 55.27 & 14.13 & 2.26 & 0.41 & 0.42 & 0.026 \\
\hline & $\mathrm{K}_{2} \mathrm{SO}_{4}(100 \mathrm{mg} / \mathrm{ll})$ & 56.88 & 14.39 & 2.30 & 0.41 & 0.42 & 0.069 \\
\hline & $\mathrm{K}_{2} \mathrm{SO}_{4}(200 \mathrm{mg} / \mathrm{l})$ & 57.66 & 15.01 & 2.40 & 0.44 & 0.48 & 0.021 \\
\hline \multirow[t]{5}{*}{$60 \%$} & Control & 46.19 & 12.47 & 2.00 & 0.40 & 0.46 & 0.023 \\
\hline & Kaolin 3\% & 48.50 & 14.26 & 2.28 & 0.40 & 0.48 & 0.023 \\
\hline & Kaolin 6\% & 54.34 & 13.74 & 2.20 & 0.40 & 0.48 & 0.028 \\
\hline & $\mathrm{K}_{2} \mathrm{SO}_{4}(100 \mathrm{mg} / \mathrm{l})$ & 52.68 & 14.31 & 2.29 & 0.45 & 0.47 & 0.046 \\
\hline & $\mathrm{K}_{2} \mathrm{SO}_{4}(200 \mathrm{mg} / \mathrm{l})$ & 50.77 & 14.26 & 2.28 & 0.41 & 0.46 & 0.048 \\
\hline \multirow[t]{5}{*}{$40 \%$} & Control & 43.49 & 12.03 & 1.93 & 0.37 & 0.41 & 0.012 \\
\hline & Kaolin 3\% & 47.66 & 12.91 & 2.07 & 0.41 & 0.42 & 0.020 \\
\hline & Kaolin 6\% & 46.89 & 13.52 & 2.16 & 0.38 & 0.44 & 0.016 \\
\hline & $\mathrm{K}_{2} \mathrm{SO}_{4}(100 \mathrm{mg} / \mathrm{l})$ & 47.98 & 13.21 & 2.11 & 0.38 & 0.48 & 0.017 \\
\hline & $\mathrm{K}_{2} \mathrm{SO}_{4}(200 \mathrm{mg} / \mathrm{l})$ & 47.23 & 14.48 & 2.32 & 0.40 & 0.47 & 0.015 \\
\hline LSD at $5 \%$ & & 1.45 & 1.45 & 0.13 & n.s & 0.05 & 0.003 \\
\hline
\end{tabular}


cucumber growth. Potassium plays a vital role in improving the photosynthetic capacity, water used efficiency, participatory in the biosynthesis of metabolic compounds, and improving in plant growth.

\section{Stomata opening area}

Leaf stomatal area was negatively affected by drought and the different treatments used that is reliable with the results of wheat leaves (Table 2). Several studies showed that drought induced a decrease in stomatal size (Martinez et al. 2007; Xu and Zhou 2008) indicating that such a phenomenon may increase the adaptation of plants to drought. Plant response to drought stress is the decrease in leaf area and plant growth that lets plants to lowering their transpiration, in consequences increasing water use efficiencies and raising interspecies competition ability under drought (Aguirrezabal et al. 2006).

Anti-transpirants were classified according to their action role: metabolic materials which are chemical compounds such as $\mathrm{K}_{2} \mathrm{SO}_{4}$ that prevents stomatal opening completely by stimulating the guard cells around the stomata pore. So, it leads to the inhibition of the loss of water vapor from plant leaves (Anjum et al. 2011). MacRobbie (2006) demonstrated that potassium accumulating in guard cells in large quantity mainly in vacuole leads to stomata opening. Accumulation of $\mathrm{K}^{+}$into the vacuole against the electrochemical gradient is necessary to generate sufficient turgor for stomatal opening.

Kaolin may be used as a foliar anti-transpirant in a form of water emulsion; it forms a thin film on leaves, which polymerizes under the effect of sunlight, reaching high resistance and elasticity. Such film reduces the escape of water from the plant by decreasing stomatal conductance, decreasing transpiration losses, improving plant water status, and decreasing wilting and leaf abscission. It is considered as a safe substance for the environment (Faralli et al. 2016).

\section{Photosynthetic pigments}

Treatment of wheat plants with different concentrations of kaolin and $\mathrm{K}_{2} \mathrm{SO}_{4}$ significantly increased photosynthetic pigments under different water levels as compared with the corresponding WHC (Table 3). The water stress that affects plant development has a negative response to photosynthesis (Abd Allah et al. 2016). Drought stress disrupts the photosynthetic pigments producing irreversible damage to the photosynthetic apparatus, decreasing gas exchange, leading to a decrease in plant growth and productivity (Anjum et al. 2011). The inhibition in chlorophyll content in most stressed plants might be due to the disorganization of thylakoid membranes, with more degradation than a synthesis of chlorophyll through the formation of proteolytic enzymes, like chlorophyllase, that is responsible for degrading chlorophyll and damaging the photosynthetic apparatus (Rong-Hua et al. 2006). Ripley et al. (2007) found that water stress might reduce photosynthetic assimilation by both stomatal and metabolic limitations.

Foliar application of kaolin evaluates its ability to decrease the negative effects of water stress and to improve the physiology and productivity of plants and alleviates the adverse effects of water stress on photosynthesis in almond trees or walnut trees (Rosati et al. 2006). Denaxa et al. (2012) found that kaolin improved the photosynthetic rate under water-deficit conditions by increasing photosynthesis levels in olive plants. Moreover, Lombardini et al. (2005) observed a positive effect on the chlorophyll index after treatment with kaolin. This increment in chlorophyll content might be because of the reality that leaves not treated with kaolin could show a lower light reflectance, indicating an increased degradation of the photosynthetic pigments (Dinis et al. 2016). Recently, it has been found that kaolin treatment in a grapevine plant increased photochemical reflectance and photosynthetic pigments (Dinis et al. 2018).

Treatment of wheat plants with different concentrations of $\mathrm{K}_{2} \mathrm{SO}_{4}$ significantly increased photosynthetic pigments under different water levels. Asgharipour and Heidari (2011) found that treatment with $\mathrm{K}_{2} \mathrm{SO}_{4}$ increased significantly the chlorophyll content with an increase in $\mathrm{K}$ supply and increase in the frequency of irrigation. In addition, $\mathrm{K}$ plays an important role in the formation of photosynthetic pigment by preventing decomposition of newly formed Chl and $\delta$-aminolevulinic acid (ALA) synthase formation (Tanaka and Tsuji 1980). These results indicate that the application of $\mathrm{K}+$ is connected with the tolerance of wheat plants to water stress by enhancing the biosynthesis of photosynthetic pigments.

\section{Carbohydrates, proline, and free amino acid}

The data in (Table 4) also demonstrated that the application of potassium sulfate had a significant effect on carbohydrate accumulation in wheat plants under water stress. It has been reported that the total soluble carbohydrates increased under drought stress, which played an important role in osmotic adjustment, carbon storage, and radical scavenging in two linseed varieties (Bakry et al. 2012). Cherel (2004) demonstrated that K played an important role in the balancing of membrane potential and turgor, activating enzymes, and regulating osmotic pressure and stomata movement. Furthermore, K improves the solute accumulation, reducing the osmotic potential, and preserves the cell turgor even under waterlimited conditions Marschner (2012).

In addition, Abd Allah et al. (2016) and El Bassiouny et al. (2018) reported the accumulation of proline in plant tissues because of various abiotic stresses which might play an important part against oxidative damages caused 
by reactive oxygen spices (ROS) owing to its action as a single oxygen quencher.

Treatment of wheat leaves with kaolin caused a marked decrease in proline accumulation as compared with the corresponding control plants. The decrease in proline content by anti-transpirant treatments is likely to be due to a direct increase of mRNA protein synthesis (Shanan and Shalaby 2011). Kaolin-treated plants showed lower contents of proline (Dinis et al. 2016), which supports the thought that this particle film is a protecting factor for wheat growing under drought and high-temperature conditions. On the other hand, foliar application with antitranspirant kaolin positively affected proline of the tested plants compared with control treatment (El Mantawy and El Bialy 2018). Dayer et al. (2013) reported that the application of kaolin gradually increases the accumulation of carbohydrates reserved in the perennial tissue. Ibrahim and Selim (2010) suggested that a foliar spray with kaolin reduced the transpiration rate, which in turn maintained higher water content in plant tissues, possibly favoring plant metabolism, physiological processes, photosynthetic rate, carbohydrate metabolism, and many other important functions that directly affect plant growth. Recently, kaolin treatment in grapevine plant increased soluble proteins, soluble sugars, and starch concentrations (Dinis et al. 2018).

\section{Lipid peroxidation}

Results revealed that wheat plant exposed to $60 \%$ and $40 \%$ of WHC showed a gradual and significant increase in malondialdehyde (MDA) compared to a control plant at $80 \%$ of WHC (Table 5). This may be due to the proline accumulation and antioxidant enzymes activity (Tables 4 and 5) which has an adaptive significance, as they detoxify the oxygen free radicals and so decreasing the oxidative stress-related membrane failure under water stress. At the same time, potassium plays a key role in lowering ROS production by decreasing the activity of NAD (P) $\mathrm{H}$ oxidases and preserving photosynthetic electron transport (Cakmak 2005).

The effects of kaolin application on lipid peroxidation in the wheat leaf are shown in (Table 5). Kaolin exhibited low values for MDA content as compared with the corresponding control at WHC percentage. The application of kaolin induced the activation in the antioxidant systems to decrease the lipid peroxidation compared to the control. It is recognized that lipid peroxidation could produce cellular damage by reacting with other lipids, proteins, and nucleic acids and prevent membrane injury in some plants (Beis and Patakas 2012; El Bassiouny et al. 2018). In addition, kaolin treatment decreased lipid peroxidation reactive substances in grapevine plant (Dinis et al. 2018).

\section{Antioxidant enzymes}

Drought stress can promote ROS production which induced the degradation of proteins and membranes, decreasing photosynthesis and plant growth (El Bassiouny et al. 2018). POX and CAT convert $\mathrm{H}_{2} \mathrm{O}_{2}$ into water and molecular oxygen, which are harmless to plants (Moller et al. 2007). These results were in good harmony with the results obtained by Bernardo et al. (2017). Kaolin particle film could induce SOD and CAT activities under stress. POX, APX, and CAT considerably increased SOD activity under salt stress to convert $\mathrm{O}_{2}{ }^{-}$to $\mathrm{H}_{2} \mathrm{O}_{2}$ that is consequently detoxified (Singh et al. 2012). Moreover, berries treated with kaolin have been correlated with a lowering of ROS, supporting the alleviation of adverse abiotic climatic stresses (Dinis et al. 2016).

There was an increment in CAT activity with increasing $\mathrm{K}$ levels. The increasing rates adversely affected the activities of SOD in wheat plants (Marques et al. 2014) and in eggplants.

\section{Minerals nutrition}

The results in Table 6 demonstrated that foliar spray at different concentrations of kaolin and $\mathrm{K}_{2} \mathrm{SO}_{4}$ on wheat plants under various levels of WHC caused a significant increase in the $\mathrm{N}, \mathrm{K}$, and $\mathrm{Ca}$ contents as compared with the corresponding $\mathrm{WHC}$ levels, while $\mathrm{P}$ was gradually decreased.

Bafeel and Moftah (2008) suggested that foliar spray with kaolin could lead to a reduction in the transpiration rate, which in turn maintained higher water content in the plant tissues and increased the mobility of nutrient to plants.

Potassium application significantly influenced the leaf potassium and sodium concentration in wheat plants (Table 6). The reduction in sodium content could be attributed to potassium competition with sodium for binding sites on the plasma membrane that repressed $\mathrm{Na}$ absorption (Al-Uqaili 2003). Application of potassium sulfate gradually increases the uptake of essential nutrients, $\mathrm{N}, \mathrm{P}, \mathrm{K}$ and $\mathrm{Ca}$, that could increase metabolic activities, which enhanced growth and productivity (Ashraf et al. 2015). Hussain et al. (2013) stated that potassium is an essential nutrient element for plant growth.

\section{Yield components}

The results in Table 7 showed the influence of different concentrations of kaolin and $\mathrm{K}_{2} \mathrm{SO}_{4}$ on yield parameters of wheat plants subjected to different levels of WHC. It could be suggested that using anti-transpirant causes a covering layer on the surface foliage that decreased the transpiration rate. Furthermore, it keeps more water in plant tissues that would reflect a favorable effect on plant metabolism and photosynthetic rate and increased outward transportation of photosynthesis from the foliage of the tomato fruits, which is important for the best plant growth, yield, and quality (Cantore et al. 2009). 
Kaolin application particularly under water stress conditions induced an increase in the yield of different crops (Coniberti et al. 2013). They included that both filmforming and stomata-closing compounds are capable to increase the leaf resistance to water vapor loss improving plant water use to assimilate carbon and production of biomass or yield (Tambussi and Bort 2007). Mohadeseh et al. (2013) reported that the sprayed kaolin at concentrations of $3.75 \%$ gradually increased the grain yield of wheat. Kaolin treatment of $1.25 \%$ gave the highest biological yield.

Ashraf et al. (2011) found that the application of $\mathrm{K}_{2} \mathrm{SO}_{4}$ stimulates wheat grain yield by improving growth conditions. Armita et al. (2017) observed the significant increases in yield components of tomato due to potassium fertilization. Also, Elayan et al. (2018) demonstrated that foliar potassium enhanced the plants' growth and the seed yield/fed of cotton plants.

\section{Carbohydrate percentage and protein percentage of the grain yield}

Foliar spray of different concentrations of kaolin and $\mathrm{K}_{2} \mathrm{SO}_{4}$ to wheat plants under the different levels of WHC caused increases in carbohydrate percentage and protein percentage as compared with the corresponding WHC levels (Table 8). Ibrahim and Selim (2010) suggested that foliar spray with kaolin reduced the transpiration rate, which in turn maintained higher water content in plant tissues, possibly favoring plant metabolism, physiological processes, photosynthetic rate, carbohydrate metabolism, and many other important functions that directly affect plant growth. Bernardo et al. (2017) suggested that kaolin may cause the global DNA de-methylation and consequently the regulation of transcriptional changes on genes associated to the DNA methylation/demethylation and lead to the formation of protein.

Potassium sulfate has a central role in the production of many important proteins which are necessary to report stress resistance in plants (Lee et al. 2009). The increase in yield and its components was due to the role of $\mathrm{K}$ for enhancing different enzyme activation, photosynthesis, protein synthesis, osmoregulation, energy transfer, stomatal movement, cation-anion balance, and stress resistance (Wang et al. 2013).

\section{Mineral nutrients of the grain yield}

Foliar spray of different concentrations of kaolin and $\mathrm{K}_{2} \mathrm{SO}_{4}$ under different levels of WHC caused a significant increase in $\mathrm{N}$ percentage, $\mathrm{K}$ percentage, and $\mathrm{Ca}$ percentage as compared with the corresponding WHC levels (Table 8). Decreasing soil moisture may decrease nutrient mobility and its availability. Erdal et al. (2007) obtained similar results on tomato. The data in Table 8 indicate that there is a significant increment percentage of $\mathrm{N}, \mathrm{P}, \mathrm{K}$, and Ca concentrations compared with the untreated plants. The obtained results are consistent with the most previous investigations, which pointed out the same direct correlation between antitranspirant materials and some element nutrient to tissues of soya bean (Yadav and Dashora 2003).

Kausar et al. (2016) reported that the nutrient uptake and accumulation such as $\mathrm{Ca}, \mathrm{Mg}, \mathrm{K}$, and $\mathrm{P}$ were gradually increased by $\mathrm{K}$ application particularly under saline environments in both wheat genotypes. Abd ElSamad et al. (2018) found that the potassium application that increased significantly gained the highest percentage values of total soluble solids (TSS), protein, N, P, and K of bean plants.

\section{Conclusion}

This paper summarizes that kaolin and potassium sulfate ameliorated the adverse effects of water stress, enhanced wheat plant growth by affecting biosynthesis of the plant's bioactive compounds like compatible solute (total soluble sugars, proline, total free amino acid) and antioxidant enzyme activities (superoxide dismutase, catalase, peroxidase,), and decreased lipid peroxidation. Moreover, foliar application of kaolin or $\mathrm{K}_{2} \mathrm{SO}_{4}$ on wheat plants gave higher nutritional value, macronutrients $(\mathrm{N}, \mathrm{P}, \mathrm{K}, \mathrm{Ca})$, and carbohydrate and protein percentage in seed yield. Interestingly, the present study recommended that kaolin may ameliorate plant physiology and consequently led to a higher yield production, and it could be a safe substance for the environment. Potassium is a necessary nutrient and its ability controls some biochemical and physiological responses in plants.

\section{Abbreviation}

CAT: Catalase; POX: Peroxidase; $\mathrm{K}_{2} \mathrm{SO}_{4}$ : Potassium sulfate; $\mathrm{ROS}$ : Reactive oxygen species; SOD: Superoxide dismutase; WHC: Water holding capacity

\section{Acknowledgements}

The authors acknowledge the National Research Centre for funding the work

Authors' contributions

MMSA, HMSE, and MAS designed the study, contributed to farming the plants, performed the experiment, are responsible for all the physiological and biochemical analysis, and also wrote and reviewed the manuscript. All authors read and approved the final manuscript.

\section{Funding}

The paper was funded by an internal project of the National Research Centre. The number of the project is 11030130 and the principal investigator is Prof. Dr. Hala Mohamed Safwat El Bassiouny.

Availability of data and materials Not applicable.

Ethics approval and consent to participate Not applicable.

Consent for publication Not applicable. 


\section{Competing interests}

The authors declare that they have no competing interests.

\section{Author details}

${ }^{1}$ Botany Department, Agriculture and Biology Division, National Research Centre, 33 El Bohouth St. Dokki, P.O. Box 12622, Giza, Egypt. ²Plant Nutrition Department, Agriculture and Biology Division, National Research Centre, 33 El Bohouth St, Dokki, P.O. 12622, Giza, Egypt.

Received: 11 July 2019 Accepted: 6 August 2019

Published online: 20 August 2019

\section{References}

Abd Allah MM, Abdelgawad ZA, El-Bassiouny HMS (2016) Alleviation of the adverse effects of salinity stress by trehalose two rice varieties. S Afr J Bot 103:275-282

Abd El-Samad EH, Shafeek MR, Abd El-Al FS, Adam SM, Behairy AG (2018) Effect of potassium fertilization and salicylic acid foliar application on growth, yield and quality of bean plants. Biosci Res 15(3):2520-2533

Abdelaziz ME, Abdeldaym EA (2018) Cucumber growth, yield and quality of plants grown in peatmoss or sand as affected by rate of foliar applied potassium. Biosci Res 15(3):2871-2879

Aguirrezabal L, Bouchier-Combaud S, Radziejwoski A, Dauzat M, Cookson SJ, Granier C (2006) Plasticity to soil water deficit in Arabidopsis thaliana: dissection of leaf development into underlying growth dynamic and cellular variables reveals invisible phenotypes. Plant Cell Environ 29:2216-2227

Al-Uqaili JK (2003) Potential of using drainage water for wheat production in Iraq. Emirates J Agri Sci 15:36-43

Anjum SA, Wang L, Faroog M, Xue L, Ali S (2011) Fulvic acid application improves the maize performance under well-watered and drought conditions. J Agron Crop Sci 197(6):409-417

Armita D, Rahayu AP, Maghfoer MD, Fuadi DAF (2017) Effect of potassium fertilization on the yield and quality of two tomato varieties. Biosci Res 14(4): $1150-1155$

Asgharipour MR, Heidari M (2011) Effect of potassium supply on drought resistance in sorghum: plant growth and macronutrient content. Pak J Agri Sci 48(3):197-204

Ashraf M, Afzal M, Ahmad R, Ali S (2011) Growth and yield components of wheat genotypes as influenced by potassium and farm yard manure on a saline sodic soil. Soil Environ 30:115-121

Ashraf M, Muhammad SS, Arif MS, Riaz M, Ali S, Abid M (2015) Effects of potassium sulfate on adaptability of sugarcane cultivars to salt stress under hydroponic conditions. J Plant Nutr 38(13):2126-2138

Bafeel SO, Moftah AE (2008) Physiological response of eggplants grown under different irrigation regimes to antitransplant treatments. Saudi J Biol Sci 15(2): 259-267

Bakry AB, El-Hariri DM, Sadak MS, El-Bassiouny HMS (2012) Drought stress mitigation by foliar application of salicylic acid in two linseed varieties grown under newly reclaimed sandy soil. J Appl Sci Res 8(7):3503-3514

Bakry AB, Ibrahim FM, Abdallah MMS, El-Bassiouny HMS (2016) Effect of banana peel extract or tryptophan on growth, yieldand some biochemical aspects of quinoa plants under water deficit. Int J Pharm Tech Res 9(8):276-287

Bates LS, Waldren RP, Teare ID (1973) Rapid determination of free proline for water stress studies. Plant Soil 39:205-207

Beis A, Patakas A (2012) Relative contribution of photoprotection and antioxidative mechanisms to differential drought adaptation ability in grapevines. Environ Exp Bot 78:173-183

Bernardo S, Dinis L-T, Luzio A, Pinto G, MónicaMeijón LV, Conde A, Gerós H, Correia CM, Moutinho-Pereira J (2017) Kaolin particle film application lowers oxidative damagemand DNA methylation on grapevine (Vitisvinifera L.). Environ Exp Bot. https://doi.org/10.1016/j.envexpbot.2017.04.002

Cakmak I (2005) The role of potassium in alleviating detrimental effects of abiotic stresses in plants. J Plant Nutrition Soil Sci 168:521-530

Cantore V, Pace B, Albrizio R (2009) Kaolin-based particle film technology affects tomato physiology, yield and quality. Environ Exp Bot 66:279-288

Chapman, H.O., Pratt, P.E., 1978. Methods of analysis for soils, plants and water. University of California.J Agri Sci Priced Publ 4034, 50

Chen JX, Wang XF (2006) Plant physiology experimental guide.24-25. Higher Education Press, Beijing, pp 55-56

Cherel $L$ (2004) Regulation of K+ channel activities in plants: from physiological to molecular aspects. J Exp Bot 55:337-351
Conde A, Pimentel D, Neves A, Dinis L-T, Bernardo S, Correia CM, Gerós H, MoutinhoPereira J (2016) Kaolin foliar application has a stimulatory effect on phenylpropanoid and flavonoid pathways in grape berries. Front Plant Sci 7:1150 Coniberti A, Ferrari V, Dellacassa E, Boido E, Carrau F, Gepp V (2013) Kaolin over sun-exposed fruit affects berry temperature, must composition and wine sensory attributes of sauvignon blanc. Eur J Agron 50:75-81

Dayer S, Prieto JA, Galat E, Perez Pefla J (2013) Carbohydrate reserve status of Malbec grapevines after several years of regulated deficit irrigation and crop load regulation. Aust J Grape Wine Res 19:422-430

Denaxa NK, Roussos PA, Damvakaris T, Stournaras V (2012) Comparative effects of exogenous glycine betaine, kaolin clay particles and ambiol on photosynthesis, leaf sclerophylly indexes and heat load of olive cv. Chondrolia Chalkidikis under drought. Scienttttia Horticulturae 137:87-94

Dinis LT, Bernardo S, Conde A, Pimentel D, Ferreira H, Felix L, Geros H, Correia CM, Moutinho-Pereira J (2016) Kaolin exogenous application boosts antioxidant capacity and phenolic content in berries and leaves of grapevine under summer stress. J Plant Physiol 191:45-53

Dinis LT, Ferreira H, Pinto G (2016) Kaolin-based, foliar reflective film protects photosystem II structure and function in grapevine leaves exposed to heat and high solar radiation. Photosynthetica 54:47-55

Dinis LT, Malheiro AC, Luzio A, Fraga H, Ferreira H, Gonçalves I, Pinto G, Correia CM, Moutinho-Pereira J (2018) Improvement of grapevine physiology and yield under summer stress by kaolin-foliar application: water relations, photosynthesis and oxidative damage. Photosynthetica 56(2):641-651

El Bassiouny HMS, Abd El-Monem AA, Abdallah MMS, Soliman KM (2018) Role of arbuscularmycorrhiza, a-tocopherol andnicotinamide on the nitrogen containing compounds and adaptation of sunflower plant to water stress. Biosci Res 15(3):2068-2088

El Mantawy RF, El Bialy M (2018) Effect of antitranspirants application on growth and productivity of sunflower under soil moisture stress. Nat Sci 16(2):92-106

El Sebai TN, Abdallah MMS, El-Bassiouny HMS, Ibrahim FM (2016) Amelioration of the adverse effects of salinity stress by using compost,Nigella sativa extract or ascorbic acid in quinoa plants. Int J Pharm Tech Res 9(6):127-144

Elayan SED, Abdullah AM, Makram EAO, Darwish AAA, Abd El-Hady AS (2018) Effect of potassium foliar fertilization, level and time of nitrogen application on growth and yield of Egyptian cotton. Biosci Res 15(2): 1103-1112

Erdal II, Ertek A, Senyigit U, Koyuncu MA (2007) Combined effects of irrigation and nitrogen on some quality parameters of processing tomato. World J Agri Sci 3(1):57-62

Faralli M, Ivan GG, Martin CH, Roger DB, Kevin SW, Fiona MKC, Peter SK (2016) Canopy application of film antitranspirants over the reproductive phase enhances yield and yield-related physiological traits of water-stressed oilseed rape (Brassica napus). Crop Pasture Sci 67(7):751-765

Fathi A, Tari DB (2016) Effect of drought stress and its mechanism in plants. Int J Life Sci 10:1-6

Golldack DQ, Michalowski F, Kamasani UR, Bohnert HJ (2003) Salinity stress tolerant and sensitive rice regulate AKT1- type potassium channel transcript differently. Plant Molecular Biol 51:71-81

Herbert D, Phipps PJ, Strange RE (1971) Chemical analysis of microbial cells. Methods Microbiol. 5B:209-343

Homme PM, Gonzalez B, Billard J (1992) Carbohydrate content, fructose and sucrose enzyme activities in roots, stubble and leaves of rye grass (Loliumperenne L.) as affected by sources / link modification after cutting. J Plant Physiol 140:282-291

Hussain Z, Khattak RA, Irshad M, Eneji AE (2013) Ameliorative effect of potassium sulphate on the growth and chemical composition of wheat (Triticumaestivum L.) in salt-effected soils. J Soil Sci Plant Nutr 13(2): 401-415

Ibrahim EA, Selim EM (2010) Effect of irrigation intervals and antitranspirant (kaolin) on summer squash (Cucurbita pepo L.) growth, yield, quality and economics. J Soil Sci Agri Eng, Mansoura University 1(8):883-894

Kausar A, Ashraf MY, Gull M, Ghafoor R, Ilyas M, Zafar S, Niaz M, Akhtar N, Kanwal H, lqbal N, Aftab K (2016) Alleviation of salt stress by K2SO4 in two wheat (TriticumAestivum L.) cultivars. Appl Ecol Environ Res 14(5):137-147

Khalil S.E., 2006.Physiological study on sesame plants grown under saline water irrigation condition. PhD thesis, Cairo University 229

Kumar KB, Khan PA (1982) Peroxidase and polyphenol oxidase in excised ragi (Eleusinecoracana cv. PR 202) leaves during senescence. Indian J Exp Bot 20:412-416 
Lee BV, Dikiy A, Kim HY, Gladyshev VN (2009) Functions and evolution of seleno protein methionine sulfoxide reductases. Biochim Biophys Acta Gen Subj 1790(11):1471-1477

Lichtenthaler HK, Buschmann C (2001) Chlorophylls and carotenoids: measurement and characterizationby UV-VIS spectroscopy. In: Wrolstad RE, Acree TE, An H, Decker EA, Penner MH, Reid DS, Schwartz SJ, Shoemaker CF, Sporns $P$ (eds) Current protocols in food analytical chemistry (CPFA). Wiley, New York, pp F4.3.1-F4.3.8

Lombardini L, Glenn DM, Harris MK (2005) Effects of particle film application on Leaf gas exchange, water relations, nut yield, and insect populations in mature pecan trees. Hort Science 40:1376-1380

MacRobbie EA (2006) Osmotic effects on vacuolar ion release in guard cells. Proc Natl Acad Sci USA 103(4):1135-1140

Marques DJ, Broetto F, Ferreira MM, da Silva Lobato AK, de Ávila FW, Pereira FJ (2014) Effect of potassium sources on the antioxidant activity of eggplant. Revista Brasileira de Ciência do solo 38:1836-1842

Marschner P (2012) Marschner's mineral nutrition of higher plants, 3rd edn. Academic, London, pp 178-189

Martinez JP, Silva $H$, Ledent JF, Pinto M (2007) Effect of drought stress on the osmotic adjustment, cell wall elasticity and cell volume of six cultivars of common beans (Phaseolus vulgaris L.). Eur J Agron 26:30-38

Mohadeseh N, Paknejad F, Moarefi M (2013) Effect of concentrations and time of kaolin spraying on wheat Aphid. J Biol Environ Sci 7(21):163-168

Moller IM, Jensen PE, Hansson A (2007) Oxidative modifications to cellular components in plants. Annu Rev Plant Biol 58:459-481

Nakano A, Uehara Y (1996) The effect of kaolin clay on cuticle transpiration in tomato. Acta Hortic 440:233-238

Predieri S, Norman HA, Krizek DT, Pillai P, Mirecki RM, Zimmerman RH (1995) Influence of UV-B radiation on membrane lipid composition and ethylene evolution in Doyenne d' Hiver pear shoots grown in vitro under different photosynthetic photon fluxes. Environ Exp Bot 35:151-160

Ripley BS, Gilbert ME, Ibrahim DG, Osborne CP (2007) Drought constraints on C4 photosynthesis: stomatal and metabolic limitations in C3 and C4 subspecies of Alloteropsissemialata. J Exp Bot 58:1351-1363

Rong-Hua L, Pei-Guo G, Baum M, Grando S, Ceccarelli S (2006) Evaluation of chlorophyll content and fluorescence parameters as indicators of drought tolerance in barley. Agric Sci China 5:751-757

Rosati A, Metcalf SG, Buchner RP, Fulton AE, Lampinen BD (2006) Physiological effects of kaolin applications in well-irrigated and water-stressed walnut and almond trees. Annu Bot 98:267-275

Saifullah A, Ranjha M, Yaseen M, Akhtar MF (2002) Response of wheat to potassium fertilization under field conditions. Pak J Agri Sci 39(4):269-272

Segura-Monroy S, Uribe-Vallejo A, Ramirez-Godoy A, Restrepo-Diaz H (2015) Effect of kaolin application on growth, water use efficiency, and leaf epidermis characteristics of physalisperuviana I.seedlings under two irrigation regimes. J Agri Sci Technol 17:1585-1596

Shanan NT, Shalaby AE (2011) Influence of some chemical compounds as antitranspirant agents on vase life of Monsteradeliciosa leaves. Afr J Agri Res 6:132-139

Siddique M, Hamid RB, Islam MA (1999) Drought stress effect on photosynthetic rate and leaf gas exchange of wheat. Bot Bull Academia Sinica 40:141-145

Singh SP, Singh Z, Swinny EE (2012) Climacteric level during fruit ripening influences lipid peroxidation and enzymatic and non-enzymatic antioxidative systems in Japanese plums (Prunussalicina Lindell). Postharvest Biol Technol 65:22-32

Snedecor GW, Cochran WG (1980) Statistical methods 7th ed. The lowa State Univ., Press, Ames

Tambussi EA, Bort J (2007) Water use efficiency in C3 cereals under Mediterranean conditions: a review of physiological aspects. Ann Appl Biol 150:307-321

Tanaka A, Tsuji H (1980) Effects of calcium on chlorophyll synthesis and stability in the early phase of greening in cucumber cotyledons. Plant Physiology 65: $1211-1215$

Wang M, Zheng Q, Shen Q, Guo S (2013) The critical role of potassium in plant stress response. Int J Mol Sci 14:7370-7390

Xu ZZ, Zhou GS (2008) Responses of leaf stomatal density to water status and its relationship with photosynthesis in a grass. J Exp Bot 59(12):3317-3325

Yadav NR, Dashora LK (2003) Shelflife of swat pepper (Capsicum annuum L.) CV. California wonder as influenced by benzyl adenine and vapor grad. Advances in Horticulture and Forestay 9:215-221
Yemm EW, Cocking EC (1955) The determination of amino acids with ninhydrin. Analyst 80:209-213

Yemm EW, Willis AJ (1954) The respiration of barley plants. IX. The metabolism of roots during assimilation of nitrogen. New Phytot 55:229-234

\section{Publisher's Note}

Springer Nature remains neutral with regard to jurisdictional claims in published maps and institutional affiliations.

\section{Submit your manuscript to a SpringerOpen ${ }^{\circ}$ journal and benefit from:}

- Convenient online submission

- Rigorous peer review

- Open access: articles freely available online

- High visibility within the field

- Retaining the copyright to your article

Submit your next manuscript at $\boldsymbol{\nabla}$ springeropen.com 